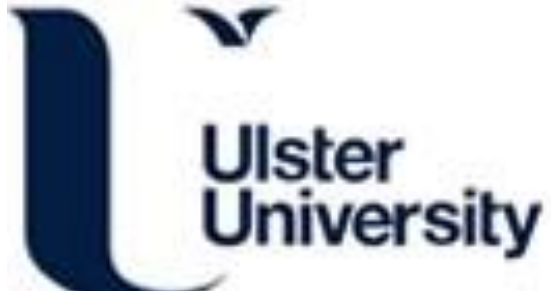

\section{Experimental performance characterisation of a Hybrid Photovoltaic/Solar Thermal Façade module compared to a flat Integrated Collector Storage Solar Water Heater module}

Smyth, M., Mondol, J., Pugsley, A., Zacharopoulos, A., \& Besheer, A. (2019). Experimental performance characterisation of a Hybrid Photovoltaic/Solar Thermal Façade module compared to a flat Integrated Collector Storage Solar Water Heater module. Renewable Energy, 137, 137-143.

https://doi.org/10.1016/j.renene.2018.04.017

Link to publication record in Ulster University Research Portal

Published in:

Renewable Energy

Publication Status:

Published (in print/issue): 31/07/2019

DOI:

10.1016/j.renene.2018.04.017

\section{Document Version}

Version created as part of publication process; publisher's layout; not normally made publicly available

\section{General rights}

Copyright for the publications made accessible via Ulster University's Research Portal is retained by the author(s) and / or other copyright owners and it is a condition of accessing these publications that users recognise and abide by the legal requirements associated with these rights.

\section{Take down policy}

The Research Portal is Ulster University's institutional repository that provides access to Ulster's research outputs. Every effort has been made to ensure that content in the Research Portal does not infringe any person's rights, or applicable UK laws. If you discover content in the Research Portal that you believe breaches copyright or violates any law, please contact pure-support@ulster.ac.uk. 


\title{
Experimental performance characterisation of a Hybrid Photovoltaic/ Solar Thermal Façade module compared to a flat Integrated Collector Storage Solar Water Heater module
}

\author{
M. Smyth", A. Pugsley, G. Hanna, A. Zacharopoulos, J. Mondol, A. Besheer, A. Savvides \\ Centre for Sustainable Technologies, School of the Built Environment, Ulster University, Newtownabbey, BT37 0QB Northern Ireland, UK
}

\section{A R T I C L E I N F O}

Article history:

Received 29 June 2017

Received in revised form

30 March 2018

Accepted 4 April 2018

Available online $\mathrm{xxx}$

\section{Keywords:}

Renewable Energy Systems

ICSSWH

PV

Hybrid

Thermal diode

\begin{abstract}
A B S T R A C T
A modular Hybrid Photovoltaic/Solar Thermal (HyPV/T) Façade technology that utilizes Integrated Collector Storage (ICS) solar technology, providing cost effective solar PV and thermal energy collection for direct use in the building, whilst providing significant thermal insulation has been developed and evaluated experimentally at Ulster University. The HyPV/T system, based upon a patented ICS solar thermal diode concept and shaped into a flat modular profile incorporating PV cells/module can provide space heating, domestic water heating and power generation. The complete system is designed to be compatible with traditional façade structures and fenestration framing arrangements, facilitating direct integration into new and retrofit building applications.

The experimental performance of HyPV/T unit has been determined and compared with a flat Integrated Collector Storage Solar Water Heater (ICSSWH) under constant indoor solar simulated conditions. The daily thermal collection efficiencies for the 'traditional' flat ICSSWH units performed better than the unglazed $\mathrm{HyPV} / \mathrm{T}$, by $5-10 \%$. However, when the additional electrical power produced by the HyPV/T is included, the overall system collection efficiencies are more equal. The heat retention performance shows that's the unglazed (bare) ICS unit had a retention efficiency of $8.3 \%$ whilst the ICS unit with a single transparent cover was $23.6 \%$ and double glazed unit was $28 \%$. The HyPV/T heat retention efficiencies were approximately $65 \%$ over the same cool-down period.
\end{abstract}

() 2018 Elsevier Ltd. All rights reserved.

\section{Introduction}

The Energy Performance of Buildings Directive (EPBD) and Renewable Energy Framework Directive (REFD) require that Renewable Energy Systems (RES) are actively promoted in offsetting conventional fossil fuel use in buildings. A better appreciation of solar systems integration will directly support this objective, leading to an increased uptake in the application of renewables in buildings. By integrating these systems into the building elements (walls, roofs, etc.) not only means replacing a conventional building material (and associated costs), but also aesthetically integrating it into the building design leads to improved architectural integration.

Integrated Collector Storage Solar Water Heaters (ICSSWH) are simple, low cost solar devices and as such offer a suitable

\footnotetext{
* Corresponding author.

E-mail address: m.smyth1@ulster.ac.uk (M. Smyth).
}

technology to partially meet the demands of the EPBD. Domestic solar thermal water heaters with integrated collectors and storage (ICS) offer cost and space efficiency benefits compared to conventional systems where the collectors and storage tanks are separate. These benefits would be further enhanced by combining the ICS with PV and locating all of the equipment within (rather than on the surface of) building façade and roof constructions. The development of ICS systems is detailed in Smyth et al. [1] and more recently by Singh et al. [2], along with their tendency to suffer significant ambient heat loss, especially at night-time and during non-collection periods. Many studies have been carried out focusing on the improvement of the thermal performance of ICSSWH systems (Quinlan [3]; Souliotis et al. [4]; De Beijer's [5]; Smyth et al. [6]). Besheer et al. [7] present an extensive review of recent approaches for hybrid PV/T solar technology. This paper presents the performance of a novel Hybrid Photovoltaic/Solar Thermal (HyPV/T) Façade Module compared with a flat ICSSWH module. The HyPV/T offers an interesting solution to mitigating the ICS heat loss problem, whilst providing a multi-functional device 
that addresses many of the wider issues facing solar devices deployed on buildings.

The ability for a single product to offer multiple functionality in a unique modular design that incorporates ICS technology, presents a huge commercial opportunity. The HyPV/T whilst offering a more cost effective solar investment will combine performance and quality and be fit for purpose, robust, visually appealing and exceptionally easy to install. These characteristics are expected in all premium solar collector-related products.

\section{Description of the HyPV/T and flat ICSSWH modules}

Two prototype units were designed, fabricated and investigated at Ulster. The performance of the rudimentary ICSSWH prototype without PV and without a transparent cover was initially quantified to establish a benchmark. Variants of the ICSSWH prototype were subsequently tested to determine the effect of different transparent cover arrangements. The behaviour of the HyPV/T prototype was then characterised and compared against the results of the ICSSWH benchmark. Fig. 1 depicts both completed HyPV/T (left) and flat ICSSWH (right) modules under the solar simulator ready for testing.

The flat ICSSWH unit(s) was based on an elliptical (Egyptian eye) profile with external dimensions $1000 \mathrm{~mm} \times 1000 \mathrm{~mm}$ and $150 \mathrm{~mm}$ deep. The ICS vessel was made from stainless steel sheet to form the collector/storage element which was supported by an internal exo-skeleton of 4 structural ribs giving a total storage volume of $35.65 \mathrm{~L}$. The absorbing surface of the ICS vessel was coated using matt black paint and the entire vessel enclosed in an outer wooden/polystyrene foam insulation case. The initial test was undertaken with an uncovered bare absorber surface. Subsequent tests were undertaken with a single cover ( $2 \mathrm{~mm}$ Perspex) and a double cover (10 $\mathrm{mm}$ transparent polypropylene twin-wall) over the absorber aperture.

The HyPV/T module was based around two principle elements; the thermal diode and water storage tank. Both elements were formed from folded and welded stainless steel sheet supported internally by an array of stainless steel tubular struts. A welded vacuum flange was added to enable working fluid addition and chamber evacuation through the top of the unit. A stainless steel manifold plate was welded to the bottom to enable connection of the evaporator wetting mechanism. The unit was approximately $1400 \mathrm{~mm}$ long, $700 \mathrm{~mm}$ wide and $190 \mathrm{~mm}$ deep and had a storage volume of $100 \mathrm{~L}$. The photovoltaic-thermal absorber was formed on the diode's absorber-evaporator plate using matt black paint, double-sided adhesive foam tape, quartered mono-crystalline silicon cells (30 Bosch M-2BB high efficiency pseudo-square cells), transparent silicone resin and transparent Perspex cover plates. The series-parallel interconnected PV cells were connected to an $8.6 \Omega$ resistive load bank. Thermally insulating polystyrene foam was applied to the rear and sides of the prototype along with a transparent Perspex sheet to cover the absorber. Fig. 2 gives a general arrangement of the HyPV/T module.

The thermal diode ICSSWH presented is an adapted version of the technology presented by Smyth et al. [6]. The inner and outer

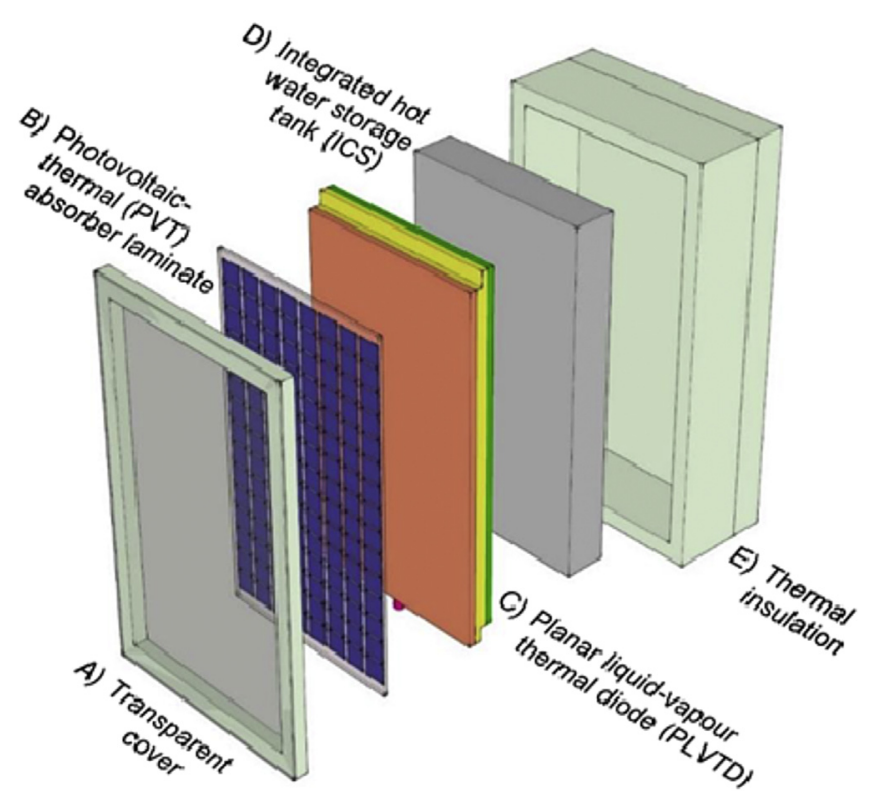

Fig. 2. General arrangement of the Hybrid Photovoltaic/Solar Thermal (HyPV/T) module.
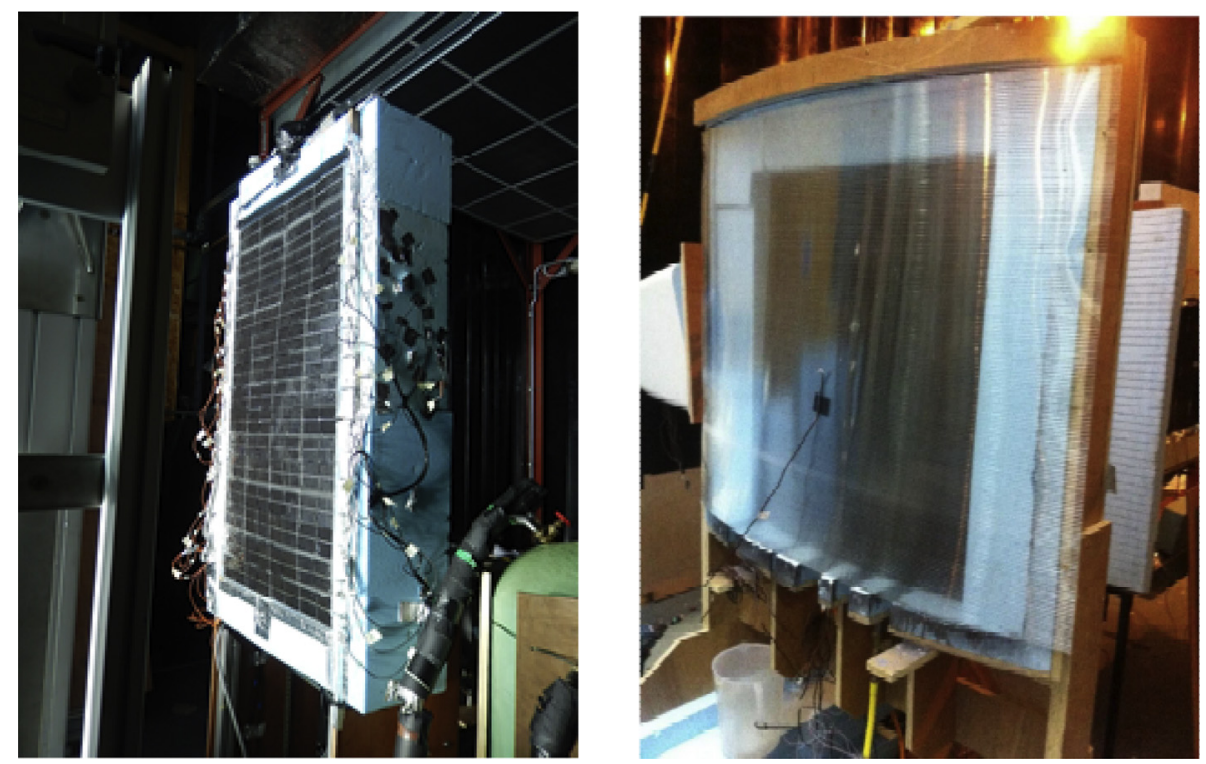

Fig. 1. Images of the HyPV/T (left) and flat ICSSWH (right) modules under solar simulation testing. 
tanks create the integral collector/storage element and the solar absorber element, respectively, which in turn produces the cavity between both vessels that is crucial to the thermal diode operation. The cavity is partially evacuated to a low pressure and contains a small amount of a liquid/vapour PCM (phase change material) heat transfer fluid. This arrangement forms the thermal diode, promoting solar collection and thermal storage though phase change processes whilst reducing thermal losses by the vacuum insulation. During collection periods, solar radiation incident on the outer surface of absorbing vessel causes the PCM in contact with the vessel wall to evaporate at low temperature thus producing a vapour. The PCM vapour condenses on contact with the colder inner (storage) vessel surface and the thermal energy is transferred to water store through latent heat exchange. Condensed PCM runs down the vessel wall to a reservoir at base of the annulus to repeat the cycle whilst the temperature of the store stratifies. During noncollection periods no evaporation takes place (no incident energy to drive the evaporation process) and because of the insulating layer created by the cavity, heat loss is reduced from the store.

\section{Description of the experimental facility}

The experimental performance of both prototypes was determined using the state-of-the-art solar simulation facility at Ulster University. The indoor solar simulator testing facility consisted of 35 high power metal halide lamps arranged in 7 rows of 5 lamps. Each lamp is equipped with a rotation symmetrical paraboloidal reflector to provide a light beam of high collimation. In order to achieve uniform distribution of light intensity on the test area, a lens is inserted in each lamp to widen the illumination of light. The combination of reflector-characteristics, lens and lamps ensures a realistic simulation of the beam path, spectrum and uniformity. The solar simulator control panel maintained the constant level light intensity automatically on the collector surface via a pyranometer mounted at the centre of the test plane. T-type copper-constantan thermocouples (error of $\pm 0.5^{\circ} \mathrm{C}$ between 0 and $70^{\circ} \mathrm{C}$ ) were used to measure the water storage temperatures within the various unit variants, surface temperatures and ambient air temperature. Water storage temperatures were measured at eight locations to record the variation of water temperature within the individual thermal stores. Temperatures were recorded through a Delta T logging device linked to a PC.

\section{Description of the experimental procedure and performance analysis}

The collection and thermal retention performance characteristics for all units were determined under solar simulated conditions. System performance characterisation was based on BS ISO 9459-5:2007 [8]. No thermal storage draw off was performed during any of the tests. The tests were conducted over time periods of between 20 and $100 \mathrm{~h}$ in order to determine the daily collection efficiency, typically consisting of $6 \mathrm{~h}$ solar simulator exposure with an average solar intensity of $600-800 \mathrm{~W} / \mathrm{m}^{2}$ followed by an $18 \mathrm{~h}$ cool down period to determine thermal retention. At the beginning of each experiment each prototype's thermal store was re-filled and the test started with steady ambient temperatures and uniform tank temperatures.

The experimental performance of each unit was determined from the experimental data retrieved from the extensive testing programme. Thermal store, absorbing and external surfaces and external environment were analysed during testing to determine the system characteristics. Thermal store characterisation used the average normalised temperatures and stratification within the store both on collection and cool down to allow analysis of collection and thermal retention efficiencies and develop hypotheses for heat transfer mechanisms into and within the thermal store.

The total amount of simulated solar energy incident on the aperture area over the test period was determined using Eq. (1).

$\mathrm{Q}_{\text {incident }}=\mathrm{I}_{\mathrm{ave}} \mathrm{A}_{\mathrm{ap}} \Delta \mathrm{t}$

where

$\mathrm{I}_{\mathrm{ave}}=\left(\int_{\mathrm{t}_{\text {end }}}^{\mathrm{t}_{\text {start }}} \mathrm{I}(\mathrm{t}) d t\right) / \Delta \mathrm{t}$

The recorded temperatures within the thermal stores were used to calculate mean temperatures in the entire storage vessel and using Eq. (3) the amount of thermal energy collected and retained was determined.

$\mathrm{Q}_{\text {col }}=\mathrm{mc}_{\text {water }}\left(\mathrm{T}_{\text {end }}-\mathrm{T}_{\text {start }}\right)$

The heat balance of the system with no draw-off is given by

$$
\begin{aligned}
& \mathrm{mc}_{\text {water }}\left(\mathrm{T}_{\text {end }}-\mathrm{T}_{\text {start }}\right)=\mathrm{I}_{\text {ave }}\left(\eta_{\text {optical }}\right) \mathrm{A}_{\mathrm{ap}} \Delta \mathrm{t} \\
& -\mathrm{UA}_{\text {system }}\left[\frac{\left(\mathrm{T}_{\text {end }}-\mathrm{T}_{\text {start }}\right)}{2}-\mathrm{T}_{\mathrm{amb}}\right] \\
& \eta_{\text {col }}=\frac{\mathrm{mc}_{\text {water }}\left(\mathrm{T}_{\text {end }}-\mathrm{T}_{\text {start }}\right)}{\mathrm{I}_{\mathrm{ave}} \mathrm{A}_{\mathrm{ap}} \Delta \mathrm{t}} \\
& \eta_{\text {col }}=\left(\eta_{\text {optical }}\right)-\frac{\mathrm{U} \mathrm{A}_{\text {system }}\left[\left(\frac{\mathrm{T}_{\text {end }}-\mathrm{T}_{\text {start }}}{2}\right)-\mathrm{T}_{\mathrm{amb}}\right]}{\mathrm{I}_{\mathrm{ave}} \mathrm{A}_{\mathrm{ap}} \Delta \mathrm{t}}
\end{aligned}
$$

Eq. (6) is superficially similar to the Hottel-Whiller-Bliss equation of solar collectors $[9,10]$, however this equation applies to a daily ICS system performance, as first proposed by Tripanagnostopoulos \& Yianoulis [11]. It should be noted that the PV and thermal diode will have an impact on collector thermal capacitance, but using a 'lumped' characterisation methodology, permits direct comparison. Plots of efficiency versus $\Delta \mathrm{T} / \mathrm{I}_{\mathrm{ave}}$ can then be used to compare efficiencies where

$\Delta \mathrm{T}=\left(\frac{\left(\mathrm{T}_{\text {end }}+\mathrm{T}_{\text {start }}\right)}{2}\right)-\mathrm{T}_{\mathrm{amb}}$

Thermal retention efficiency ( $\left.\eta_{\text {ret }}\right)$ is determined by

$\eta_{\text {ret }}=\left(\frac{\mathrm{m} \times \mathrm{c}\left(T_{\text {final }}-T_{a m b}\right)}{\mathrm{m} \times \mathrm{c}\left(T_{\text {initial }, c}-T_{a m b}\right)}\right) \times 100$

where $T_{\text {initial,c }}$ is the average temperature at the start of the cooldown period, $\mathrm{T}_{\text {final }}$ is the average temperature at the end of the cooling period and $T_{a m b}$ is the average ambient temperature throughout the cool-down period.

\section{Experimental results and discussion}

The experimental performance of the prototype Hybrid Photovoltaic/Solar Thermal (HyPV/T) unit has been determined and compared with the flat ICSSWH under constant indoor solar simulated conditions. The thermal performances of various modified HyPV/T and flat ICSSWH designs have been investigated and the thermal performance and collection efficiencies are presented.

The normalised average storage water temperatures for the 
various flat ICSSWH modules under solar simulation testing shown in Fig. 3 illustrate the heat retention benefits of an aperture cover for any BIST module. All the units exhibit an initial rapid rate of thermal collection, with the additional optical losses associated with the transparent covers having a limited but observable impact on the final store temperature. This translated into instantaneous thermal collection efficiencies under zero temperature rise conditions (equalised to ambient) of $65 \%, 64 \%$ and $62 \%$, for the unglazed (bare), single and double glazed units, respectively. During cooldown, the bare unit lost all of the collected thermal energy by the end of the test whilst the covered variants exhibited a positive gain of approximately $5^{\circ} \mathrm{C}$ in the thermal store. The inclusion of the second transparent cover proved to have small benefit (approximately $2{ }^{\circ} \mathrm{C}$ ) in improving thermal retention. The ambient temperatures were similar during all tests. The average storage water temperatures observed over the cool-down period are also mirrored in the respective heat retention efficiencies. The unglazed (bare) unit had a retention efficiency of $8.3 \%$ whilst the unit with a single transparent cover was $23.6 \%$ and double glazed unit was $28 \%$.

Fig. 4 shows the temperature time history during the 4 day collection/cool-down testing under $\mathrm{I}_{\mathrm{ave}}=610 \mathrm{~W} / \mathrm{m}^{2}$ irradiance for the HyPV/T unit with no cover. At the start of the test the water storage tank (T3) was at $16^{\circ} \mathrm{C}$ and was similar to the other unit component temperatures (T1, absorber plate; T2, condenser; $\mathrm{T} 4$, thermal diode sidewalls; $\mathrm{T}_{\mathrm{s}}$, working fluid sump). The absorber, working fluid sump, and thermal diode sidewall temperatures increased rapidly as soon as the absorber was exposed to the solar simulator (at Point "A") and began to rise rapidly (at Point "B") after about half an hour and at a lower rate thereafter. All parts of the prototype steadily increased in temperature at a broadly similar rate during the majority of the $6 \mathrm{~h}$ collection period. When the solar simulator was switched off (at Point " $\mathrm{C}$ ") the condenser (T2) and tank (T3) temperatures dropped steadily whereas the absorber, sump, and sidewalls cooled rapidly for $\sim 2 \mathrm{~h}$ (until Point "D"). For the latter part of the $18 \mathrm{~h}$ cool-down period all parts of the prototype cooled at a similar rate. Each of the 4 collection periods and 4 cooldown periods followed a similar pattern (albeit with differing temperatures) with 'dawn and dusk' temperatures increasing on subsequent days until the tank temperature reached a maximum of $\mathrm{T} 3=53^{\circ} \mathrm{C}$ before cooling overnight to $\mathrm{T} 3=44^{\circ} \mathrm{C}$. Forward mode temperature difference across the thermal diode was typically $\Delta \mathrm{T} 1$ $2 \approx 15^{\circ} \mathrm{C}$ at the start of the test (at Point " $\mathrm{A}$ ") and steadily fell to $\Delta \mathrm{T} 1-2 \approx 3{ }^{\circ} \mathrm{C}$ (at Point " $\mathrm{E}$ ") indicating that diode thermal conductance increased with temperature, as expected. The reverse mode temperature difference across the thermal diode was typically $\Delta \mathrm{T} 1$ $2 \approx-8{ }^{\circ} \mathrm{C}$ at the start of the test (at Point "A") and $\Delta \mathrm{T} 1-2 \approx-18{ }^{\circ} \mathrm{C}$ at the end (at Point "F").

The unglazed HyPV/T achieved thermal and PV efficiencies under zero temperature rise conditions (equalised to ambient) of 56\% and $9 \%$, respectively. During the continuous 4 day collection/heat retention test period (with no water draw offs), the daily collection efficiency varied from $56 \%$ on the first day (starting with a cold tank) to $38 \%$ on the last (starting with warm tank). Overnight (18hr) heat retention efficiencies were $65 \pm 5 \%$ and the overall heat loss coefficient was $1.1 \mathrm{~W} / \mathrm{m}^{2} \mathrm{~K}$.

Fig. 5 shows system efficiency plots versus $\Delta \mathrm{T} / \mathrm{I}_{\mathrm{ave}}$ (using the Hottel-Whiller-Bliss form based on Eq. (6)) for the unglazed HyPV/T against the 3 flat ICSSWH variants (unglazed, single and double glazed apertures). The unglazed flat ICSSWH exhibits the highest optical efficiency but has a steeper 'efficiency curve' gradient due to a greater heat loss. Both the glazed flat ICSSWH units have similar 'efficiency curves' with the single glazed unit exhibiting a slightly better optical performance but with more heat loss. The unglazed HyPV/T, due to the PV element has a much lower apparent optical efficiency but due to the thermal diode and the low emissivity characteristics of the PV, has better heat loss/retention characteristics. If the co-generation efficiency is considered, the additional HyPV/T electrical power means the overall system collection efficiency is more equal to the non-PV flat ICSSWH units.

An architectural evaluation of the HyPV/T system was conducted to assess the unit's modular format and its compatibility with traditional façade structures and fenestration framing arrangements, facilitating direct integration into new and retrofit building applications. The system's building integration is done by the

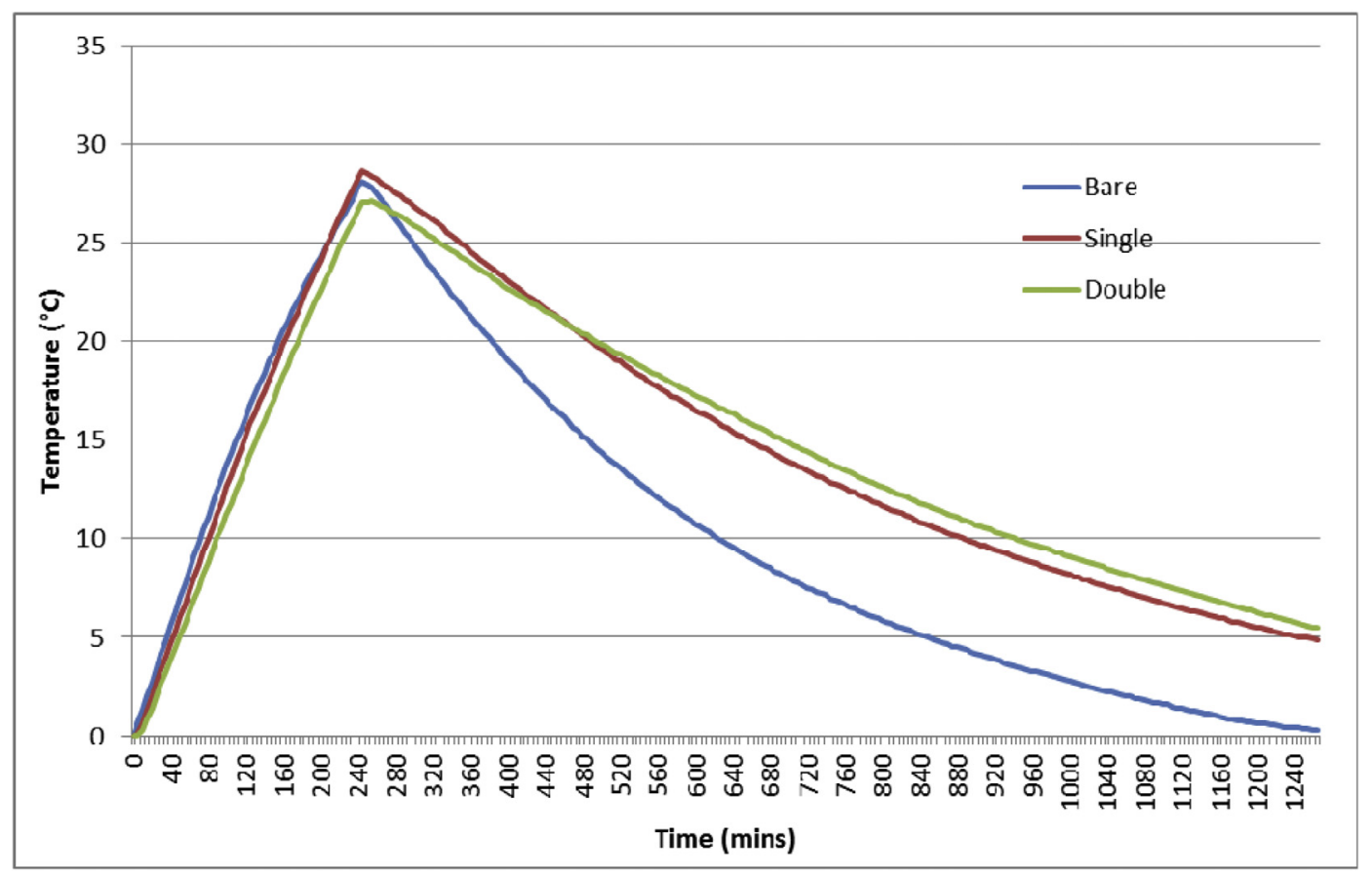

Fig. 3. Normalised (to starting temperature) average storage water temperatures for the various flat ICSSWH modules under solar simulation testing. 


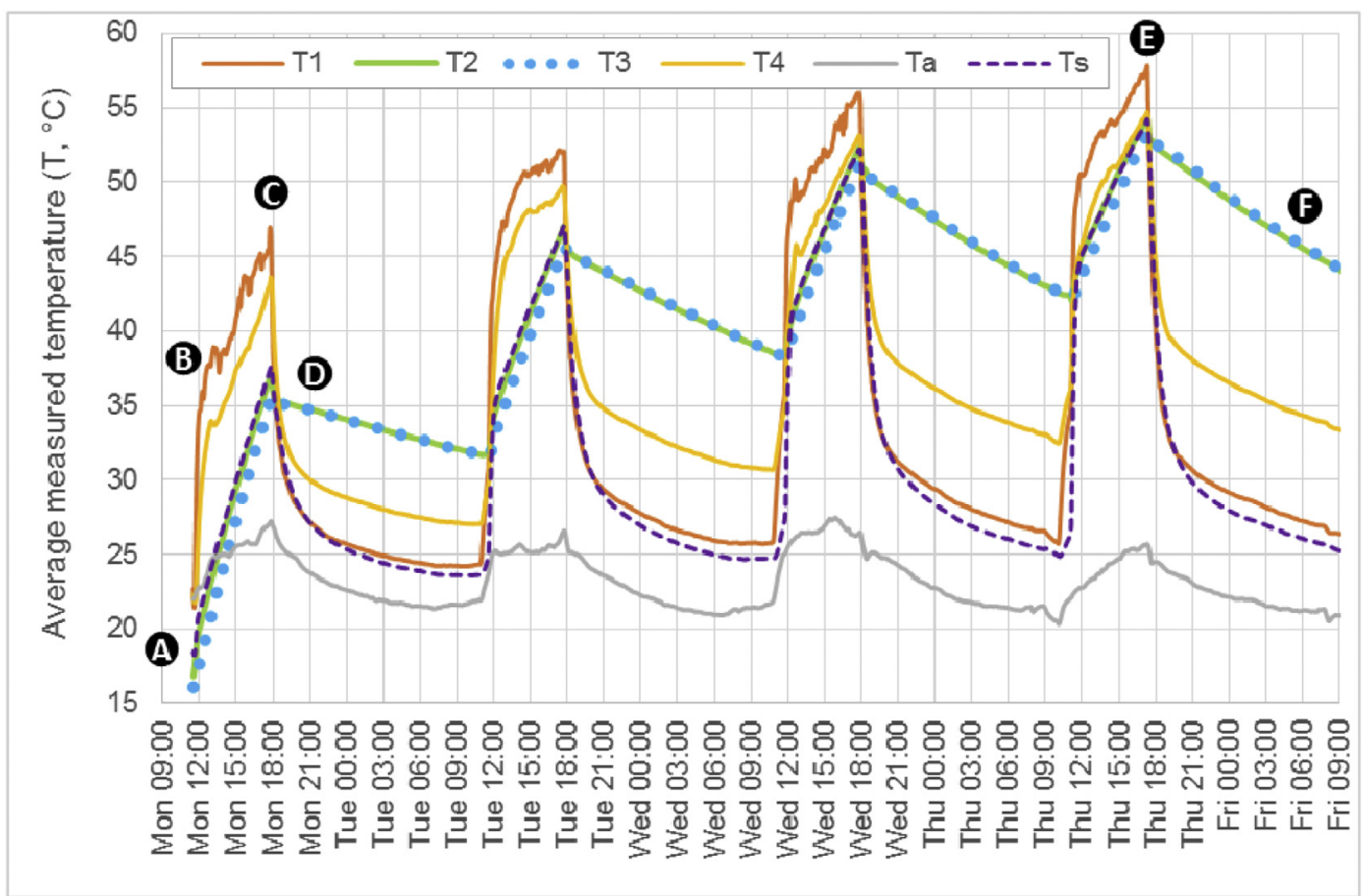

Fig. 4. Average measured temperatures for the unglazed HyPV/T unit under solar simulation testing.

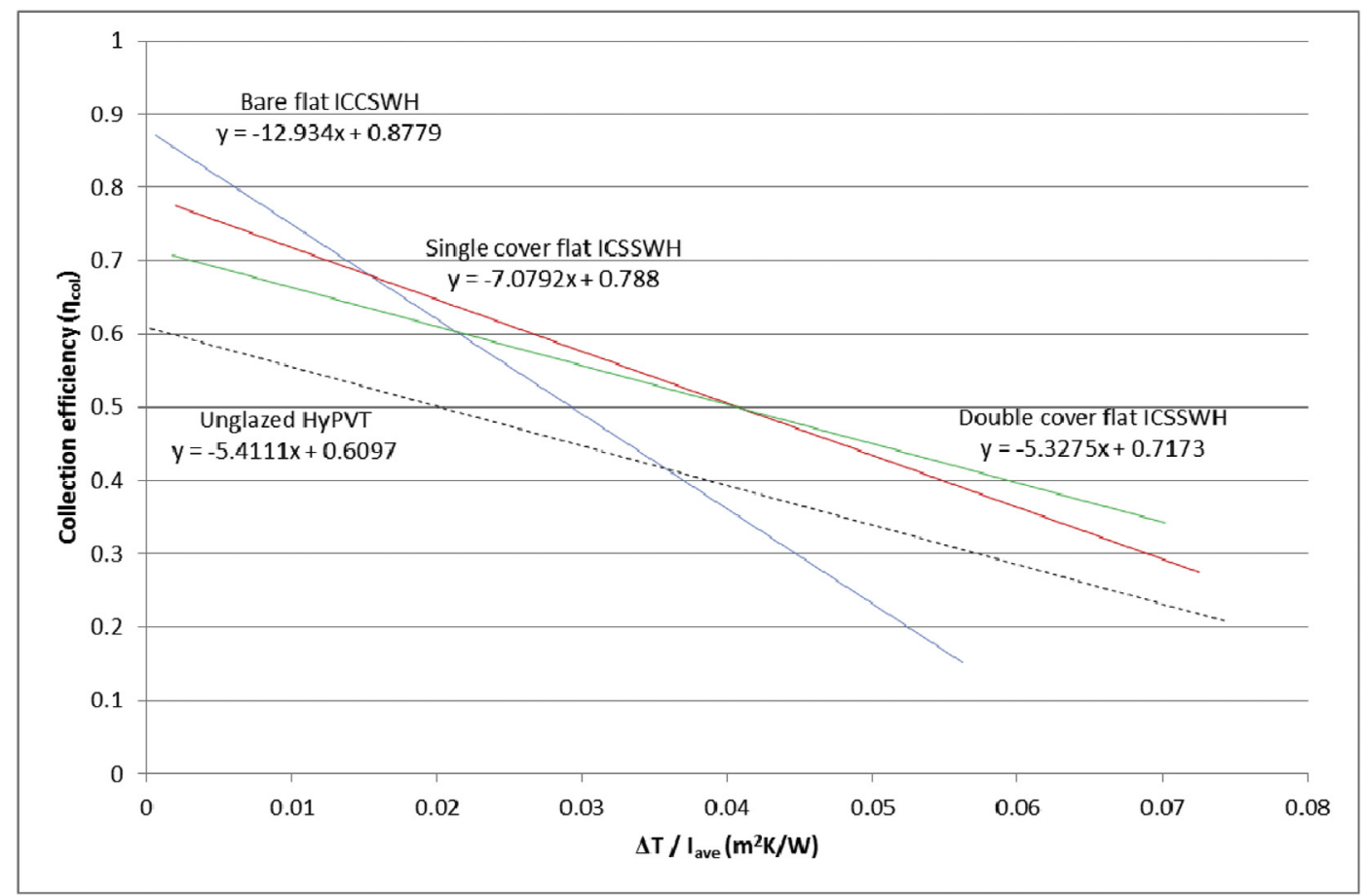

Fig. 5. Plots of efficiency versus $\Delta \mathrm{T} /$ Iave for various HyPV/T and flat ICSSWH (right) modules under solar simulation testing

accession of its surrounding metal frame on the static body of the building. This framework provides the structural efficiency of the wall to which it belongs, and also accommodates the system's piping. The system is placed within the building's masonry in such a manner that it becomes a part of it, as shown in Fig. 6. The construction is such that it can accommodate a conventional opening (e.g. window), in the position of which, the system's module is placed. The back of the system is closed with conventional masonry, in order not to be perceived internally by the users of the building. In selected internal locations, control points are placed.

The installation of the system is in such a way that the external thermal insulation and contingent waterproofing cover $1-2 \mathrm{~cm}$ of the perimeter, ensuring its adequacy for weather conditions. At the same time, this overlap provides maximum insulation because the combination of the system (which is vacuum formed) with the insulation of the shell reduces to a minimum the geometrical 


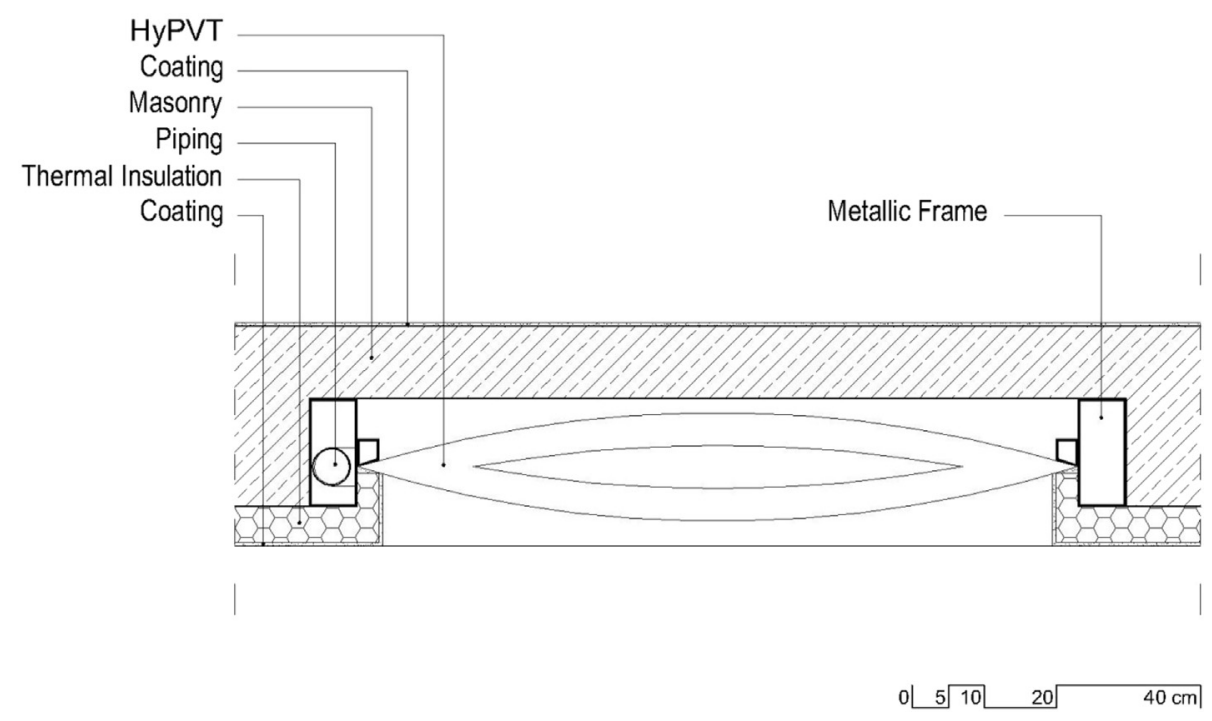

Fig. 6. Horizontal Section of the HyPV/T in a traditional façade structure/fenestration framing arrangement.

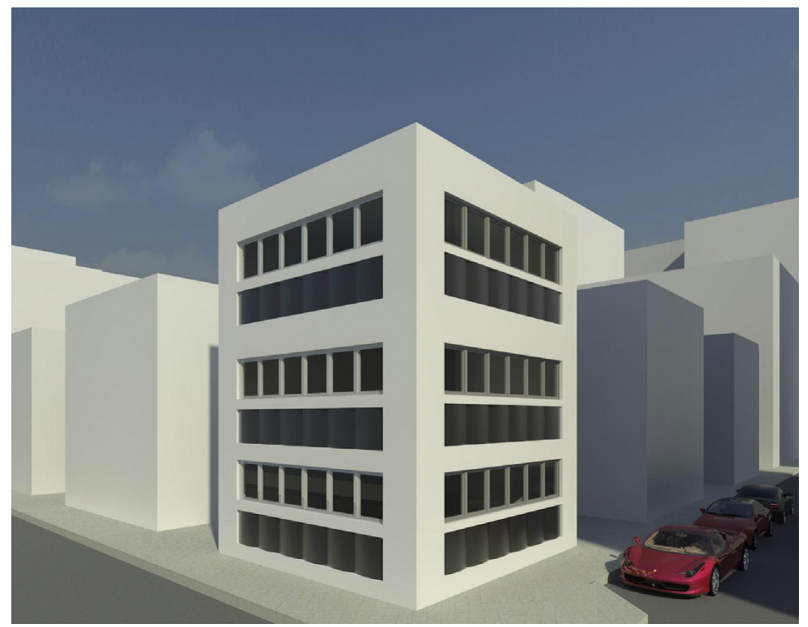

Fig. 7. Realistic visualization of the system integrated on a multi-storey building.

thermal bridges. The positioning of a second wall behind the system ensures the continuity of the shell thus providing the necessary fire safety. Furthermore, the continuity of the shell provides the necessary soundproofing. Fig. 7 presents a realistic visualization of the system integrated on a multi-storey building.

\section{Conclusions}

A modular Hybrid Photovoltaic/Solar Thermal (HyPV/T) Façade technology that utilizes Integrated Collector Storage (ICS) solar technology, potentially providing cost effective solar PV and thermal energy collection for direct use in the building, whilst providing significant thermal insulation has been developed and evaluated experimentally under the solar simulator facility at Ulster University. The HyPV/T system, based upon a patented ICS solar thermal diode concept has been tested and its thermal performance analysed and compared with a series of 'traditional' flat ICSSWH units.

The daily thermal collection efficiencies (equalised to ambient) for both systems were determined. As expected, the 'traditional' flat ICSSWH units (unglazed, single and double glazed units) performed better than the unglazed HyPV/T, by $5-10 \%$. This is also evident from the system efficiency plots shown in Fig. 5. However, when the additional electrical power produced by the HyPV/T is included, the overall system collection efficiencies are more equal. Furthermore, a glazed version of the HyPV/T could potentially improve upon the measured thermal efficiencies (albeit with a corresponding a drop in electrical conversion). The heat retention performance however is much more promising. The unglazed (bare) ICS unit had a retention efficiency of $8.3 \%$ whilst the ICS unit with a single transparent cover was $23.6 \%$ and double glazed unit was $28 \%$. The HyPV/T heat retention efficiencies were approximately 65\% over the same cool-down period.

The work presented in this paper illustrates that it is possible to design and develop a modern ICSSWH unit that can collect significant quantities of solar thermal energy and retain the energy over extended periods of non-collection. Whilst the thermal performance of the proposed HyPV/T thermal diode concept compares favourably with other forms of ICSSWH units, the multi-functional design offers additional benefits. Shaped into a flat modular profile incorporating PV cells/module the unit can provide improved thermal insulation linked to space heating with domestic water heating and power generation supplied directly to a building. The complete system is designed to be compatible with traditional façade structures and fenestration framing arrangements, facilitating direct integration into new and retrofit building applications.

\section{Acknowledgements and Funding}

This work was supported through funding from Invest Northern Ireland, Proof of Concept scheme and COST Action TU1205: Building Integrated Solar Thermal Systems.

\section{Nomenclature}

$\begin{array}{ll}\mathrm{A}_{\mathrm{ap}} & \text { aperture area }\left(\mathrm{m}^{2}\right) \\ \mathrm{c} & \text { specific heat capacity of water }(\mathrm{J} / \mathrm{kgK}) \\ \mathrm{I}_{\mathrm{ave}} & \text { average insolation }\left(\mathrm{W} / \mathrm{m}^{2}\right) \\ \mathrm{m} & \text { mass of water }(\mathrm{kg}) \\ \mathrm{Q}_{\text {incident }} & \text { incident solar thermal energy }(\mathrm{J}) \\ \mathrm{T} & \text { temperature }\left({ }^{\circ} \mathrm{C} / \mathrm{K}\right) \\ \mathrm{UA} A_{\text {system }} & \text { heat loss coefficient of system }(\mathrm{W} / \mathrm{K}) \\ \Delta \mathrm{t} & \text { time }(\mathrm{secs})\end{array}$


$\Delta \mathrm{T}$

$\eta_{\text {col }}$

ๆoptical

$\eta_{\text {ret }}$

Subscripts

a/amb average ambient temperature

end

final

initial,c

average temperature at end of heating period average final water temperature at end of cooling period average initial water temperature at start of cooling period

start average temperature at start of heating period

\section{References}

[1] M. Smyth, P.C. Eames, B. Norton, Integrated collector storage solar water heaters, Renew. Sustain. Energy Rev. 10 (6) (2006) 503-538.

[2] R. Singh, I.J. Lazarus, M. Souliotis, Recent developments in integrated collector storage (ICS) solar water heaters: a review, Renew. Sustain. Energy Rev. 54 (2016) 270-298.

[3] P. Quinlan, The Development of a Novel Integrated Collector Storage Solar Water Heater (ICSSWH) Using Phase Change Materials and Partial Evacuation,
PhD Thesis, University of Ulster, UK, 2010.

[4] M. Souliotis, P. Quinlan, M. Smyth, Y. Tripanagnostopoulos, A. Zacharopoulos, M. Ramirez, P. Yianoulis, Heat retaining integrated collector storage solar water heater with asymmetric CPC reflector, Sol. Energy 85 (10) (2011) 2474-2487.

[5] H.A. De Beijer, Product development in solar water heating, in: Proceedings of the 5th World Renewable Energy Congress, Florence, Italy, 1998, pp. 201-204. Sept. 1998.

[6] M. Smyth, P. Quinlan, J.D. Mondol, A. Zacharopoulos, D. McLarnon, A. Pugsley, The evolutionary thermal performance and development of a novel thermal diode pre-heat solar water heater under simulated heat flux conditions, Renew. Energy 113 (2017) 1160-1167.

[7] A. Besheer, M. Smyth, A. Zacharopoulos, J. Mondol, A. Pugsley, Review on recent approaches for hybrid PV/T solar technology, Int. J. Energy Res. (40) (2016) 2038-2053.

[8] Anon, Solar Heating - Domestic Water Heating Systems- Part 5: System Performance Characterization by Means of Whole-system Tests and Computer Simulation. BS ISO 9459-5:2007, British Standards Institution, London, UK, 2007a.

[9] R. Bliss, The derivation of several plate efficiency factors useful in the design of flat-plate solar-heat collectors, Sol. Energy 3 (1959) 55-62.

[10] H. Hottel, A. Whillier, Evaluation of Flat Plate Collector Performance, Trans. Conf. On the Use of Solar Energy, Tucson, Arizona, U.S.A, vol. 2, 1958, pp. 74-104.

[11] Y. Tripanagnostopoulos, P. Yianoulis, Integrated collector/storage systems with suppressed thermal losses, Sol. Energy 48 (1) (1992) 31-43. 